JKAU: Comp. IT., Vol. 1 No. 2, pp: 123-148 (2012 A.D. / 1434 A.H.)

DOI: 10.4197 / Comp. 1-2.6

\title{
Finding New KPIs for Faculty of Computing and Information Technology at KAU
}

\author{
Kamal M. Jambi, Hasanain M .Al-Barhatoshy, Wajdi AlJudaibi \\ and Radi Teleb \\ Faculty of Computing \& Information Technology \\ King Abdulaziz University, Jeddah, Saudi Arabia
}

\begin{abstract}
This paper presents key performance indicators (KPIs) for the Faculty of Computing and Information Technology (FCIT) at King Abdulaziz University (KAU). The objective of this work is to find out the answer of the following: (a) Are grades of English courses (ELCS101, ELCS102) and CPIT201 valid measures of student performance? (b) Can the Math course (MATH 110) be used as an indicator? (c) Can the GPA of the common courses of our faculty (CPCS202, CPIT201, CPIT221, STAT210, ISLS 101) be used as a measure to determine the selection of the major: Computer Science (CS), Information Technology (IT), or Information System (IS)? (d) How can we use features of IT-Blocks in our study?, and (e) The gender issue (i.e. why girls outperform boys) in our faculty?).

Also the following Key indicators can be drawn from this paper: Overall Pass Rate, Retention Rate, Program Completion Rate, Average course/year hour load and First time Graduate Students.
\end{abstract}

\section{Introduction}

Evaluating what students have learned throughout the course can be accomplished in many ways, depending on the course objectives and how student performance will be measured. Homework, class participation, research papers and tests are all traditional methods for assessment that can be created and recorded within any educational system. Moreover, projects and presentations through which students can demonstrate their understanding and mastery of course material. 


\subsection{Progress Monitoring}

On another hand, progress monitoring is a scientifically based practice that is used to assess students' academic performance and evaluate the effectiveness of instruction. Progress monitoring can be implemented with individual students or an entire class.

In order to implement progress monitoring, the student current levels of performance are determined and goals are identified for learning that will take place over time. The student academic performance is measured on some regular basis such as every week or month. Progress toward meeting the student goals is measured by comparing expected and actual rates of learning. Therefore, based on these measurements, teaching is adjusted as needed. Thus, the student progression of achievement is monitored and instructional techniques are adjusted to meet the individual student learning needs ${ }^{[1]}$.

According to that resource, if the progress monitoring is implemented correctly, the benefits are great for everyone involved which include ${ }^{[1]}$ :

- Receiving higher expectations for students by teachers;

- Acceleration in the learning process because students are receiving more appropriate instruction;

- Getting more informed instructional decisions;

- Having better documentation of student progress for accountability purposes;

- Obtaining more efficient communication with families and other professionals about student progress.

\subsection{Key Performance Indicators}

Key Performance Indicators (KPI) are quantifiable measurements, that reflect the critical success factors of an organization ${ }^{[2]}$, our faculty (FCIT) in this case. There are different KPIs depending on the organization. A business may have as one of its KPIs the percentage of its income that comes from return customers. A faculty may focus on its KPIs on graduation rates of its students. A Customer Service Department may have as one of its KPIs, in line with overall company KPIs, the percentage of customer calls answered in the first minute. A KPI for a 
social service organization might be the number of clients assisted during one year.

Therefore, whatever KPIs are selected, they must reflect the organization's goals, they must be keys to its success, and they must be measurable. KPIs are long-term considerations. Also, the goals for a particular KPI may change as the organization's goals change, or as it gets closer to achieving that goal.

\subsection{Factors Affecting Students' Performance}

This paragraph covers a local experience ${ }^{[3]}$. It is known that determinants of students' performance have been the subject of ongoing debate among educators, academics, and policy makers. There have been many studies that to examine this issue and their findings point out to hard work, previous schooling, parents' education, family income and self motivation as factors that have a significant effect on the students GPA. The aim of the study of ${ }^{[3]}$ is to investigate the socio-economic characteristics of students of the College of Business and EconomicsUAEU in relation to these students' performance and taking into account variables pertaining to the UAE Society. Using a sample of $864 \mathrm{CBE}$ student and regression analysis, the results show that the most important factor that affects student performance is the student competence in English. Besides competence in English, students who participate in class discussion and those on leave outperform other students. The factors that negatively affect student performance the most are missing too many lectures and living in a crowded household. The results also show that non-emirates students outperform national students and female students outperform their male counterpart.

$\mathrm{In}^{[4]}$ a comprehensive development of standards is provided. Here is how the new standards were developed. It started in December 1999 where 88 teachers drafted written descriptions of the student performance standards for Novice, Apprentice, Proficient and Distinguished students. In April 2000 the number of teachers increased to 960 teachers used the Contrasting Groups procedure to recommend standards. By December 2000, 292 teachers applied the CTB Bookmark procedure. The teacher panels examined test booklets in which the items were ranked according to difficulty, and then placed bookmarks at the point in the booklet where they thought the difficulty of the next test item represented a change from one performance level to the next. 
The author of thesis in ${ }^{[5]}$ focused on analyzing data from three international surveys of students' skills, PISA, TIMSS and PIRL. There are two objectives of that study. The first one is to formulate recommendations on improved provision of basic skills education in the $\mathrm{EU}$, on the basis of an increased understanding of the outcomes of the PISA, TIMSS, and PIRLS surveys. The second one is to formulate recommendations for improved or new data collection activities to cover data needs in the area of basic skills.

The analysis work of ${ }^{[5]}$ focused on conditions for the provision of basic skills at different levels: A systemic level, covering factors concerning the systemic characteristics of educational systems and the consequences for students' basic skills; A structural level, covering socio-economic background characteristics of students, the significance of these factors for students' basic skills, and the capacities of education systems to adjust for differences in students' socio-economic background; A school level, covering aspects of school management and school climate and the significance of these factors for students' basic skills; and an individual level, concerning the significance of student attitudes, motivation and learning behavior, and their consequences for students' achievements.

\subsection{The experience of Malaysia with (KPI-MS)}

Key Performance Indicator Monitoring System (KPI-MS) is an online monitoring system of Key Performance Indicator (KPI) that can be assessed anywhere and anytime. The findings of a study that assessed the Key Performance Indicators Monitoring System (KPI-MS) of a university are based on Technology Acceptance Model which are given in Balakrishnan, et al. ${ }^{[6]}$.

A total of 78 participants from all the schools and centers in one of the public universities in northern Malaysia participated in the study. A descriptive analysis was carried out to obtain the mean scores of KPI-MS as rated by the users. The findings showed that the users rated KPI-MS as a very useful system in monitoring the KPI performance of their schools or centers. Besides, users also indicated that the KPI-MS is easy to use. In conclusion, KPI-MS system is accepted by the users in terms of perceived usefulness and perceived ease of use on the system. 
In Malaysia, KPI is used as a requirement for the public higher education institutions in improving quality. The quality level of higher education institutions are determined by the effectiveness and efficiency of their performance. The benchmark of the performance indicators was determined by the Ministry of Higher Education (MoHE) Malaysia. MoHE provides the benchmarks for the KPIs in order to enable public universities in Malaysia improve in their performance. They aspire to be among the top 100 universities in the world.

Table 1: Differences between groups using the paired-samples t-test ${ }^{[7]}$.

\begin{tabular}{|l|c|c|c|c|c|c|}
\hline & $\mathbf{N}$ & $\begin{array}{c}\text { Mean } \\
(\boldsymbol{\mu})\end{array}$ & Minimum & Maximum & SD & Variance \\
\hline Usefulness Score & 78 & 46.49 & 36 & 52 & 4.927 & 24.279 \\
\hline Ease-of-use Score & 77 & 37.77 & 27 & 44 & 4.710 & 22.181 \\
\hline
\end{tabular}

The four-point scale indicates strongly disagree, disagree, agree and strongly agree. There are thirteen items for the section on "Perceived Usefulness" which scores the maximum mark of fifty two. The mean score obtained from the participants for usefulness of KPI-MS is 46.49 which signify that using KPI-MS can make their work easier. The result revealed that users strongly agree that KPI-MS is very useful.

As a conclusion of that research ${ }^{[6]}$, Users generally found that this system is truly useful in providing most of the functions needed in completing the tasks. KPI-MS is well accepted not only due to its usefulness; users also found that this system is very user-friendly and all the features introduced were necessary in enhancing their work.

\subsection{Singapore Experience}

Professor Lee Sing Kong is the Director of the National Institute of Education, from Nanyang Technological University. He gives reasons behind having the next KPIs ${ }^{[8]}$. The reasons are to define goals and targets to be achieved for each Characteristic Feature to reflect distinction, the need for empirical measures to track performance, and the need for performance benchmarks to identify both areas of excellence and areas for improvement.

\subsubsection{International Recognition for Excellence in Teacher Education}

KPI 1 No. of official VIP visits from foreign delegations and higher education institutions. 
KPI 2 10\% of academic staff invited for keynote addresses, plenary lectures, paper presentations at international conferences.

KPI $320 \%$ of academic staff provided editorial consultancies for internationally refereed journals or served as editors for proceedings of international conferences.

KPI $410 \%$ of academic staff served as external examiners or consultants to academic programs $/ \mathrm{PhD}$ theses in overseas universities.

KPI $520 \%$ of academic staff participated in international research projects.

KPI $615 \%$ of academic staff served on international boards.

KPI 7 At least 5 Distinguished Professors of international repute appointed to NIE.

KPI 8 At least 10 overseas scholars on sabbatical and research attachments to NIE.

KPI 9 Ratio of students to total academic staff at least 14:1

[KPI is in line with international benchmarks].

KPI 10 Percentage of higher degree graduates over total number of graduates.

[new KPI -baseline performance target yet to be determined].

1.5.2. Visionary, People-Oriented, Open and Effective Management and Leadership

KPI 11 Positive ratings of staff perception of management and leadership.

[KPI data is taken from staff surveys. New performance standard were derived from 2008 survey data].

\subsubsection{Highly Qualified, Competent and Committed Staff}

KPI 12 Average Teaching Index of at least 80\% -of positive feedback from trainee teachers.

KPI $1385 \%$ of academic staff with PhDs.

KPI $1470 \%$ of academic staff with formal teaching qualifications.

KPI $1510 \%$ of academic staff are full professors. staff.

KPI 16 Positive ratings on quality of administrative and support 
[KPI data is taken from staff surveys. New performance standard will be derived from 2008 survey data ].

\subsubsection{High Quality and Innovative Teaching Practices}

KPI 17 Positive ratings for satisfaction level with quality and innovative teaching approaches used by staff.

KPI $1880 \%$ of modules conducted in ICT-enriched environment.

KPI 19 At least 10 high quality and innovative teaching approaches introduced over a 3 year cycle.

1.5.5. Vibrant and Multi-Disciplinary Research Environment that Produces Excellent International Research Publications and Applications

KPI 20 At least 0.60 international refereed journal papers per academic staff.

KPI 21 At least 0.30 books per academic staff.

KPI 22 At least 0.25 chapters per academic staff.

KPI 23 At least 0.50 conference proceedings per academic staff.

KPI 24 At least 2 national / international research awards per academic year.

KPI 25 90\% of professorial staff to be research active (by 2012).

KPI 26 At least 0.10 new research projects per academic staff.

KPI $2725 \%$ of all research projects to be collaborations between AGs and research centers.

KPI 28 At least 10\%of overall research funding to come from nonMOE funding (external competitive research funding).

KPI 29 Research income per academic staff.

[New KPI that aims to measure growth in research output. Baseline yet to be determined].

KPI 30 Percentage of research funding over total budget.

[New KPI that aims to measure growth in research funding. Baseline yet to be determined].

\subsubsection{Quality Graduates who Excel and Contribute Significantly to} Society

KPI 31 Positive ratings for principals level of satisfaction with quality of NIE graduates 


\subsubsection{Warm and Conducive Working Climate which Maximizes Staff Potential, Interaction and Cooperation}

KPI 32 Positive ratings on level of staff satisfaction.

[KPI data is taken from staff surveys. New performance standard will be derived from 2008 survey data].

\subsubsection{Continuing and Enhanced Relationship within NTU and with} MOE, Alumni, Industry, International Organizations and Institutions

KPI $3350 \%$ of staff involved in providing consultancies to external agencies.

KPI 34 At least 0.10 collaborative projects per staff involving NTU, MOE, schools, industries, international institutions.

KPI 35 At least 10 active MOUs per academic year.

KPI 36 At least 3 new MOUs per academic year.

KPI 37 30\% academic staff involved in boards / committees in MOE, schools and industry.

As a conclusion of his research, he claims that KPIs must be ${ }^{[8]}$.

- Relevant to NIE's core mission and strategy.

- Responsive to changes in the external and internal landscape that may have impact on NIE achieving its vision.

- Constantly reviewed and adapted to keep up with global trends and international standards.

Also it should be noted that search continues for appropriate performance targets for KPIs with qualitative results.

\subsection{The Experience of the Islamic World}

In Riyadh, during 4-5 October 2011, the extraordinary session of Islamic Conference of Ministers of Higher Education and Scientific Research was held. The ministers agreed on some KPIs. They issued a guide for assessment and quality enhancement for universities in the Islamic world ${ }^{[9]}$. 
Table 2. KPIs proposed to the Islamic World.

\begin{tabular}{|c|c|}
\hline CRITERION & INDICATOR \\
\hline Teaching & $\begin{array}{l}\text { - Graduate employability } \\
\text { - Student enrolment and retention } \\
\text { - Ratio of faculty members with PhD to total number of faculty } \\
\text { - Frequency of curriculum reviews and development } \\
\text { - Students success rates in standardized and professional examinations } \\
\text { - Modernity of teaching references and textbooks } \\
\text { - Ratio of faculty to students } \\
\text { - Assessment of teaching quality } \\
\text { - Ratio of expenditure on non-salary items to total budget such as } \\
\text { teacher training, equipment, IT \& Library services, and student- } \\
\text { related expenditure } \\
\text { - Faculty members with awards } \\
\text { - Ratio of faculty members with terminal degrees from other } \\
\text { institutions to total number of faculty }\end{array}$ \\
\hline Research & $\begin{array}{l}\text { - Research quality } \\
\text { - Research performance } \\
\text { - Research volume } \\
\text { - External research grants and chairs } \\
\text { - Patents }\end{array}$ \\
\hline $\begin{array}{l}\text { International out- } \\
\text { look }\end{array}$ & $\begin{array}{l}\text { - Ratio of international faculty to total faculty } \\
\text { - Ratio of International students to Total students } \\
\text { - Ratio of faculty members with foreign higher degrees to total } \\
\text { number of faculty members with local degrees } \\
\text { - International cooperation } \\
\text { - International conferences organized } \\
\text { - International Exchange Programs }\end{array}$ \\
\hline $\begin{array}{l}\text { Facilities, } \\
\text { Resources, and } \\
\text { Supporting Staff }\end{array}$ & $\begin{array}{l}\text { - Number of library holdings and book titles per student } \\
\text { - Number of accessible up-to-date journals/periodicals (hard } \\
\text { and soft copies) } \\
\text { - Availability and diversity of learning materials and resources } \\
\text { - Adequacy of learning and teaching-related infrastructures } \\
\text { - University experience enhancement opportunities } \\
\text { - Adequacy of trained and skilful supporting technical and } \\
\text { office staff }\end{array}$ \\
\hline $\begin{array}{l}\text { Socio-economic } \\
\text { impact }\end{array}$ & $\begin{array}{l}\text { - Lifelong learning and community service programs } \\
\text { - Industrial linkages and Coop. programs } \\
\text { - Entrepreneurship programs } \\
\text { - Number of market linked academic majors } \\
\text { - Size of university endowments } \\
\text { - Alumni-university links } \\
\text { - The HEI's success in meeting relevant national developmental } \\
\text { demands }\end{array}$ \\
\hline
\end{tabular}

Those KPI's reflect the priorities observed in international scales. Knowledge of such priorities allows university leaders to reengineer their 
activities and re-prioritize them to achieve an improved performance that matches the quality standards. The following tables listed those KPIs.

\subsection{The Experience of Portugal}

Universities put special emphasis in the identification, analysis and working procedures, to improve the performance and provide a service of excellence. Very often the faculties or departments and those in charge of these are worlds apart from other managers, both regard the management as well as their duties. As a result of this departmenta- lization, departmental leaders are only concerned with their Faculty/Department, steering away from the goals of the institution.

As an example, in a system of university and college quality, where the competition between the institutions has increased in response to the social demand, the students should have information and background available that is truthful and that will put them in a position to make good decisions based on rational characteristics. The students have the right to know basic characteristics of the courses, such as for example the average duration of the getting degrees, the employment opportunities, or the degree of satisfaction of recent graduates.

- Number of doctors' theses with a favorable award / total number of doctorate candidates (per academic course or degree).

- Number of students enrolled in doctorate courses / Number of graduates (per academic course and degrees).

- Number of articles in magazines such as referee / Total number of researchers (per knowledge area).

- Number of books published / total number of researchers (per knowledge area).

- Number of papers presented at seminars and scientific meetings / Total number of researchers (by areas of knowledge).

- Number of projects and research contracts sponsored / Total number of researchers (by areas of knowledge).

- Number of registered patents / Number research projects (by areas of knowledge).

- Number of research groups subsidized / Total number of researchers (by areas of knowledge).

- Budget resources used in research activities / Total number of researchers (by areas of knowledge). 
- Number of students enrolled / Total number of teaching staff (per graduate and academic courses).

- Number of students enrolled / Square metres for the teaching activity and their complementary services (per degree).

- Number students enrolled / Total number of administrative staff and services (per degree).

- Number of hours for practical training in enterprises and institutions/ Total number of students enrolled (per degree).

- Number of students who failed / Total number of students enrolled (per degree).

- Number of students that complete their courses in the period set / Total number of students enrolled (per degree).

- Number of Masters and Post-graduate courses / Number of graduates (per academic course and degrees).

- Average time spent in the acquisition of investments:

- Number of hours spent in enrolments / Total number of students enrolled (per degree).

- Number of complaints made by the students.

- Average time spent in the management of an expense process.

- Number of expense processes handled / Total number of staff in administration and services in administration management services.

- Number of hours for professional training of staff / Total number of staff in administration and services.

- Number of seminars carried out, outside of the university scope / Total number of teaching and research staff.

\subsection{Sheffield Experience:}

A Strategic Plan 2010-2015 was planned in Sheffield, UK. The following are KPIs to be established during the following years.

\section{Aims and Objectives}

The paper of this research is to have answers to the following questions, some of which are taken for granted by many faculty members. These questions are:

- Are grades of English courses (ELCS101, ELCS102, CPIT221) a valid measure of student performance? 
Table 3. KPIs of the Strategic Plan 2010-2015, Sheffield, UK.

\begin{tabular}{|c|c|c|}
\hline No. & $\begin{array}{l}\text { Key Performance } \\
\text { Indicators (KPI) }\end{array}$ & Measures \\
\hline 1 & \multirow{4}{*}{$\begin{array}{l}\text { Institutional } \\
\text { sustainability }\end{array}$} & Total income per academic FTE (£s) \\
\hline 2 & & $\begin{array}{l}\text { Percentage ratio of recurrent teaching and research grants from } \\
\text { funding bodies to total income }\end{array}$ \\
\hline 3 & & $\begin{array}{l}\text { Percentage ratio of tuition fees and education contracts to total } \\
\text { income }\end{array}$ \\
\hline 4 & & $\begin{array}{l}\text { Ratio of maintenance and capital expenditure to Insurance } \\
\text { Replacement Value (IRV) }\end{array}$ \\
\hline 5 & \multirow{6}{*}{$\begin{array}{l}\text { Academic profile and } \\
\text { market position }\end{array}$} & Number of undergraduate students per academic FTE \\
\hline 6 & & Number of postgraduate taught students per academic FTE \\
\hline 7 & & Number of overseas students per academic FTE \\
\hline 8 & & Average tariff score on entry \\
\hline 9 & & Percentage of first degree entrants from state schools/colleges \\
\hline 10 & & $\begin{array}{l}\text { Percentage of first degree entrants from low participation } \\
\text { neighbourhoods }\end{array}$ \\
\hline 11 & \multirow{4}{*}{$\begin{array}{l}\text { The student } \\
\text { experience and } \\
\text { teaching and learning }\end{array}$} & Student satisfaction (overall satisfaction from NSS) \\
\hline 12 & & Percentage of First and 2:1 degrees awarded \\
\hline 13 & & $\begin{array}{l}\text { Percentage of students no longer in higher education after one } \\
\text { year }\end{array}$ \\
\hline 14 & & Percentage of graduates in further study or employment \\
\hline 15 & \multirow{4}{*}{ Research } & Research expenditure per total $£$ expenditure \\
\hline 16 & & Research income per academic FTE (£s) \\
\hline 17 & & Number of postgraduate research students per academic FTE \\
\hline 18 & & $\begin{array}{l}\text { Research Excellence Framework (REF) performance - } \\
\text { methodology to be confirmed }\end{array}$ \\
\hline 19 & \multirow{2}{*}{ Knowledge transfer } & $\begin{array}{l}\text { Licence numbers granted (software and non-software) in the } \\
\text { year }\end{array}$ \\
\hline 20 & & $\begin{array}{l}\text { Total value of contract research with non-funding organisations } \\
\text { (£s) }\end{array}$ \\
\hline 21 & \multirow[b]{2}{*}{ Financial health } & Ratio of current assets to current liabilities \\
\hline 22 & & $\begin{array}{l}\text { Net cash inflow from operating activities as a percentage of } \\
\text { total income }\end{array}$ \\
\hline 23 & \multirow{2}{*}{$\begin{array}{l}\text { Estates and } \\
\text { infrastructure }\end{array}$} & $\begin{array}{l}\text { Percentage of buildings in category A and B (gross internal } \\
\text { area: non-residential) }\end{array}$ \\
\hline 24 & & Carbon emissions (tonnes) \\
\hline 25 & \multirow{3}{*}{ Staff } & Percentage of staff who are proud of working for the University \\
\hline 26 & & Percentage of female senior academic staff (Grade 10) \\
\hline 27 & & $\begin{array}{l}\text { Percentage of professional/support staff costs to total staff } \\
\text { costs }\end{array}$ \\
\hline
\end{tabular}

- Can the Math course (MATH 110) be used as an indicator?

- Can the GPA of the common courses of our faculty (CPCS202, CPIT201, CPIT221, STAT210, ISLS 101) be used as a measure to determine the selection of a major such as: Computer Science (CS), Information Technology (IT), or Information System (IS)? 
- How can we use products of IT-Blocks in our study?

- The gender issue. (why girls outperform boys) in our Faculty?)

Also the following Key indicators can be drawn from this research:

$\checkmark$ Overall Pass Rate

$\checkmark$ Retention Rata

$\checkmark$ Program Completion Rate

$\checkmark$ Average course/year hour load

$\checkmark$ First time Graduate Students

\section{Getting Data}

The research is divided into two phases. After conducting a thorough literature review, a solid back ground will be granted. This is followed by obtaining the required and needed data by the help of Deanship of Information Technology. Some statistical processing will be done in order to get answers for the questions stated in the objectives. Sufficient time is spent for investigating the reliability of the suggested indicators..

\subsection{Obtaining and Preparing Data}

There are two sets of data obtained for this research. The first is obtained from the Deanship of Information Technology, since they are not accessible by the username of Vice Dean of FCIT. This file contains all students of FCIT with GPAs and the grades of courses in the orientation year. This includes the following courses (CPIT100, CPIT201, CP201, ELCS101, ELCS102, MATH100, MATH101, and MATH201). It should be mentioned that due to changing from the old plan to a new one, the course numbers are changed. This implies that consideration should be taken for change. Also, courses of the orientation year are changed such as MATH100, MATH110, and MATH101.

Also having several plans for the orientation years through the last four years gives us some problems regarding having a complete data set for many students. One more thing regarding the data given from the DIT where data was in different format as was expected. All the above points gave as a hard time to prepare data for processing. This forced the research team to find and outsource help to prepare data as needed. 


\section{Indicators Design Structure}

Perceived data involve several categories from many source technologies with different data description. Multiple sources of information can be used to collect data/information. The participants of such information include Customer Relationship Management (CRM), Finance, Human Resources (HR), Students Information, Research Information, and other resources, see Fig. 1.

The indicator hierarchy consists of controls derived from an indicator base class and renderers derived from a character renderer base class. The renderer base class has two supporting classes at character level, one for data and one for the segment map that defines the character display.

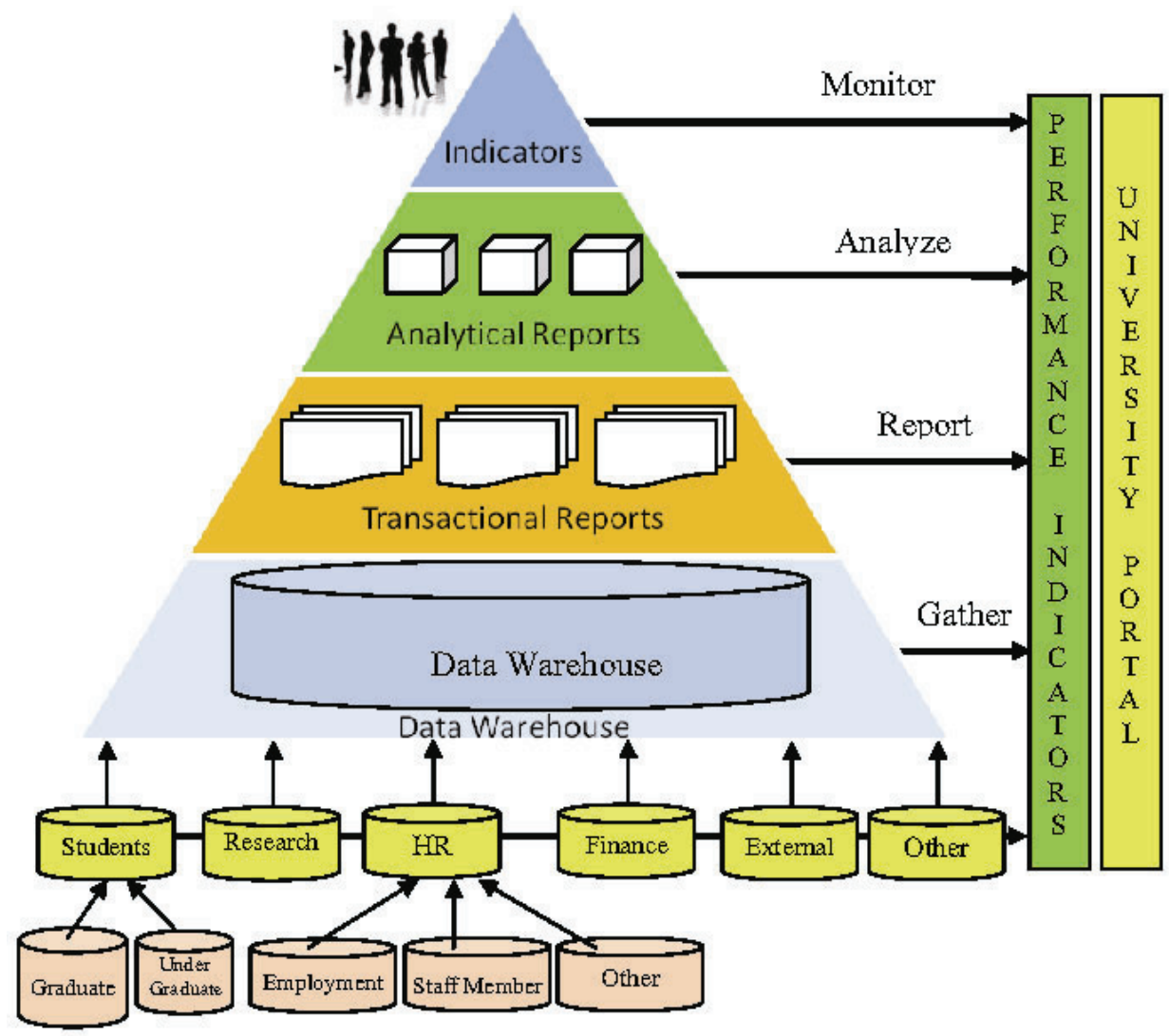

Fig. 1. Faculty internal indicator structure. 


\subsection{Implementation Tool}

Microsoft Visual Studio as an integrated development environment (IDE) from Microsoft is used. It is used to develop graphical user interface applications along with all platforms supported by Microsoft Windows. Visual Studio includes a code editor supporting IntelliSense as well as code refactoring. Other built-in tools include a forms designer for building GUI applications, web designer, class designer, and database schema designer.

The entity relationship of the proposed database is illustrated in Fig.2. This diagram includes different relations types, in addition to the types of these relations.

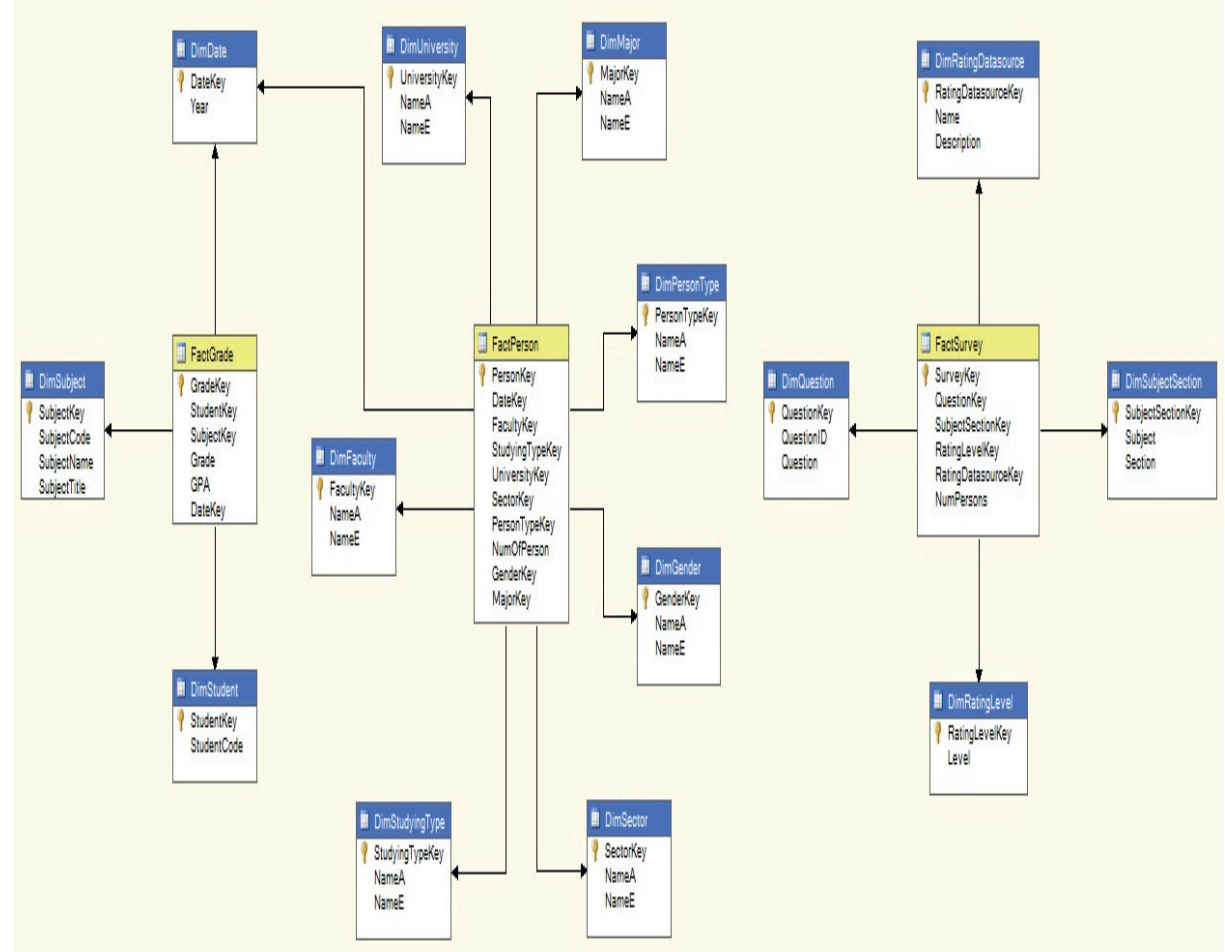

Fig. 2. The E/R diagram of the proposed system.

\subsection{Indicators Testing}

According to the previous description, Fig. 3 illustrates the KPIs for the Faculty of Computing and Information Technology in case of reliability testing within the duration of $2000-2011$. 


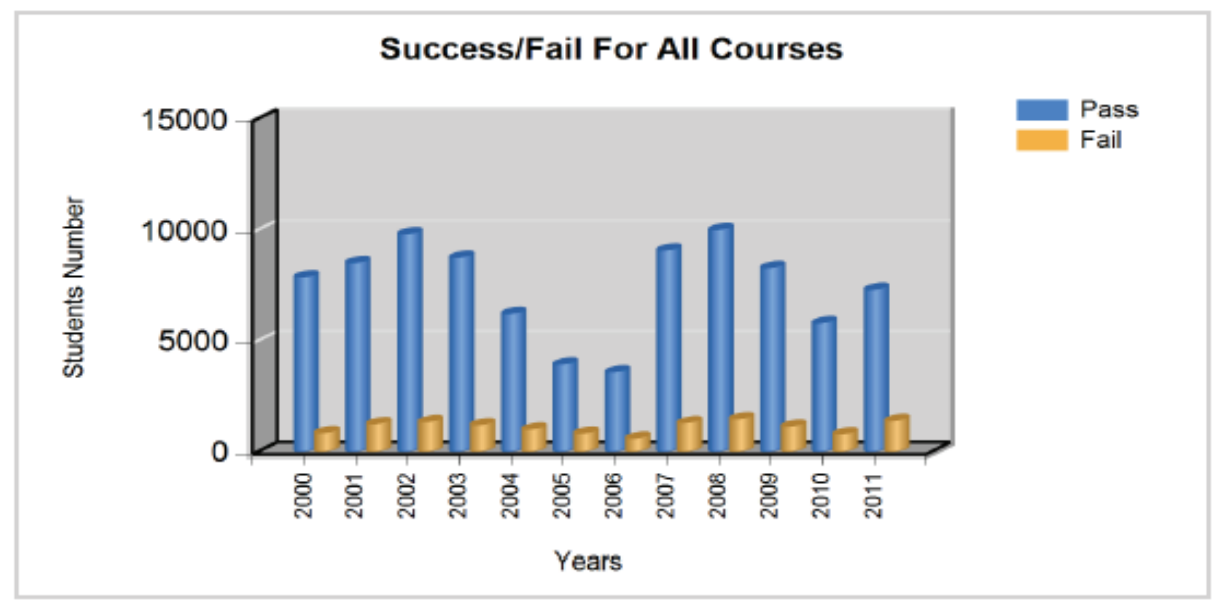

Fig. 3. Reliability testing (Success/Fail Relation).

Figure 4 shows the relation between the number of students and semesters, i.e.; pass/retention rates for all courses over semesters.

\section{Pass/Retention rates for all courses over semesters}

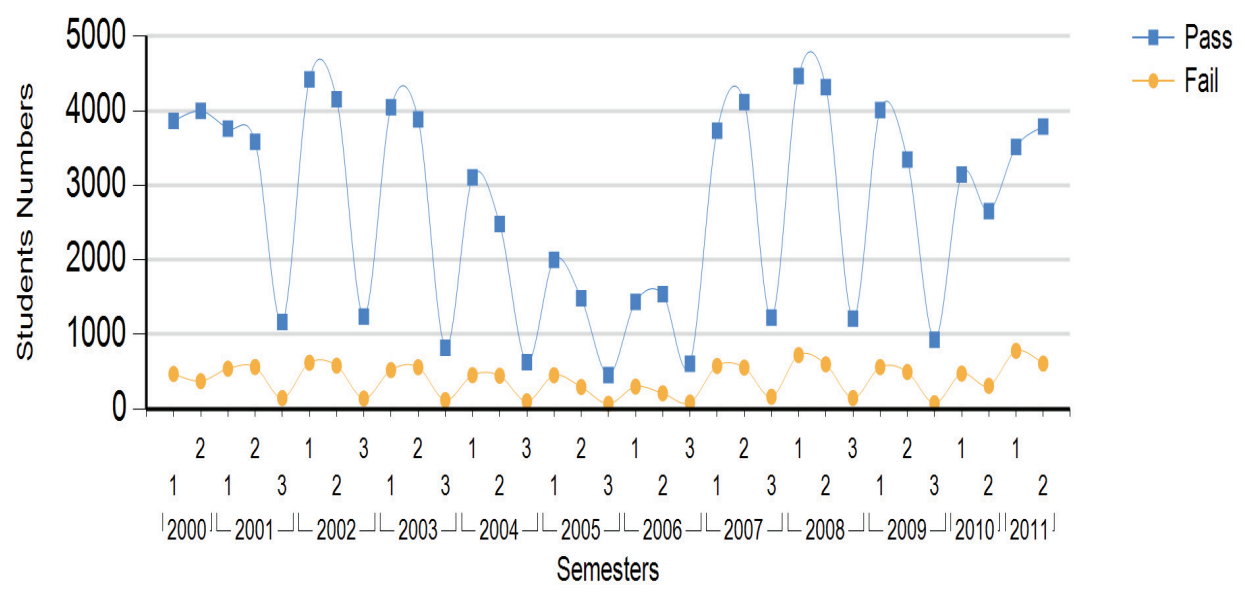

Fig. 4. Relation between students numbers and semester years.

Figure 5 displays set of marks distribution according to grades in all courses. Every indicator should be disaggregated (when relevant) by race. 


\section{Pass/Fail for all courses all years}

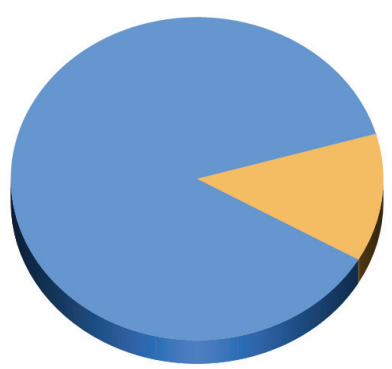

\section{Grades for all courses all years}

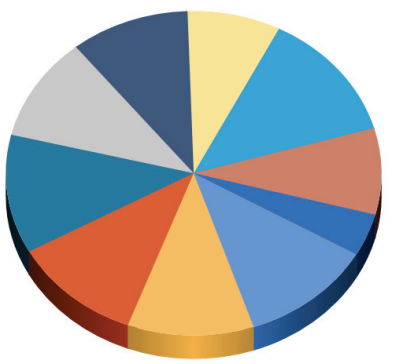

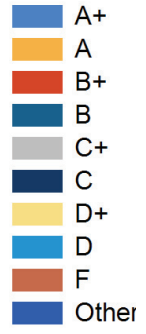

Fig. 5. Grades distribution (2000-2011).

Figure 6 indicates to the alumni students in the Faculty of Computing and Information Technology during 2007 - 2011, it includes under graduate and graduate indicators for the male and female sections.
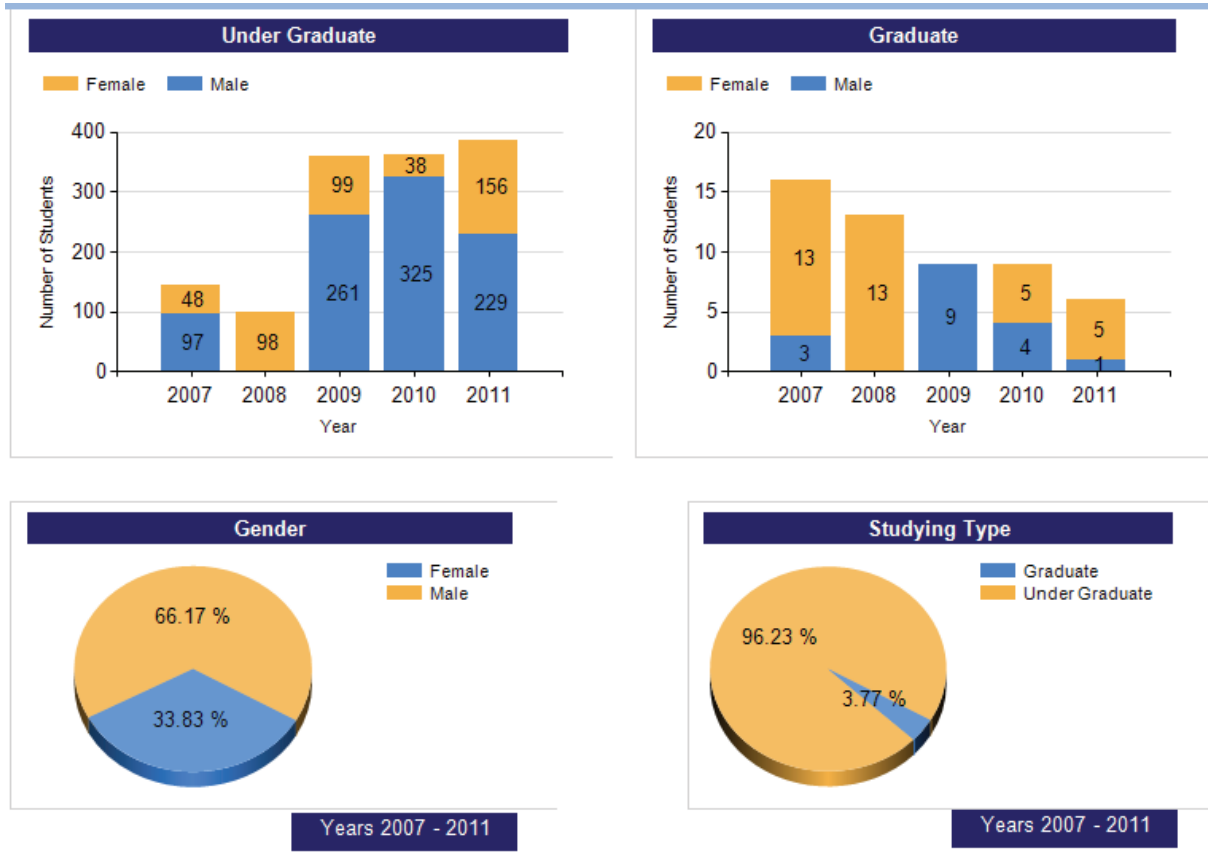

Fig. 6. Indicator of undergraduate and graduate distribution.

The total number of alumni students (accumulated value) during 2007 until 2011 is shown in Fig. 7. 

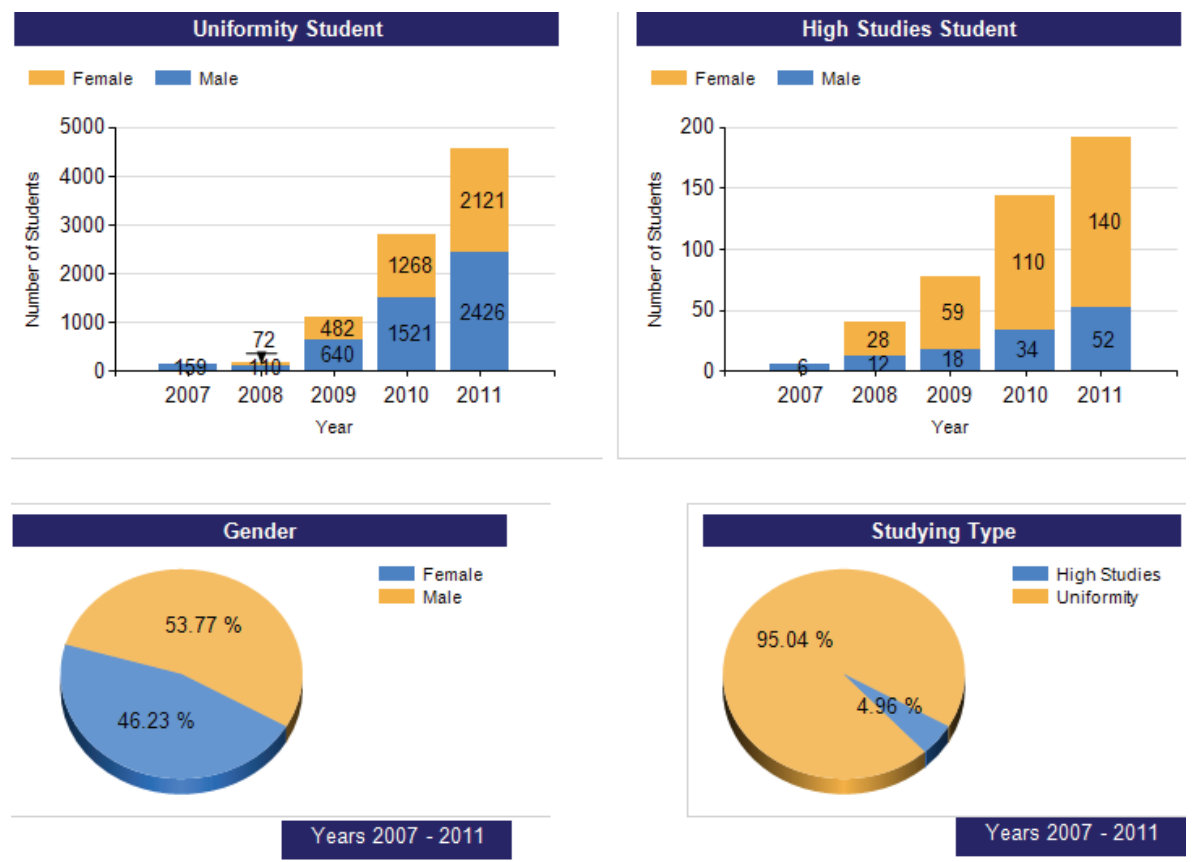

Fig. 7. Alumni student numbers indicator (2007-2011).

Staff members indicators for male and female are shown in Fig. 8. The relative value of percentage between male and female during 2010 is equal to $65 \%$ to $35 \%$.
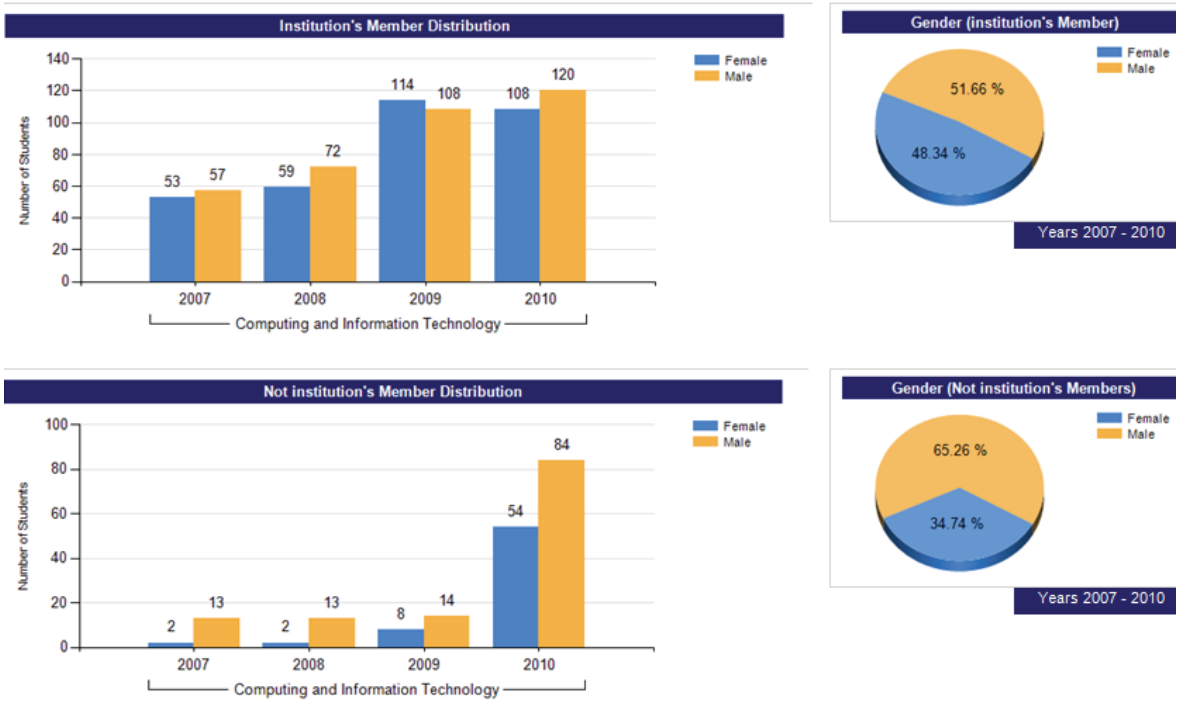

Fig. 8. Staff members indicators for male and female. 


\section{Processing Data}

The GPA of the students in FCIT can be predicted through their grades in supported courses in the preparatory year. To achieve this purpose, the development of Stepwise Multiple Regression method is used, and to know which courses are of more influence and also have influential contribution as independent variables in the GPA - as the dependent variable for the computing students, and to identify the most important decisions that explain much of the variation in the total GPA. The proposed statistical model selects the regression coefficients of independent variables that have an impact on the dependent variable (GPA), and is determined by the regression equation as follows:

$$
\mathrm{Y}=\mathrm{a}_{0}+\mathrm{b}_{1} \mathrm{X}_{1}+\mathrm{b}_{2} \mathrm{X}_{2} \ldots
$$

Where $\mathrm{Y}$ represents GPA, $\mathrm{a}_{0}$ is constant, $\mathrm{X}_{1}$ is independent variable (course), $b_{1}$ represents regression coefficient. Therefore, the following table illustrates such "Stepwise Multiple Regression" proposed method after applied in SPSS program.

The following paragraph deals with the part of the research that takes care of the marks of courses of the orientation year of students of FCIT. The main objective of this paragraph is to determine the prime course or courses that contribute to the expectation of GPA. It goes over four hypotheses as the following.

\section{Hypothesis no. 1:}

There are no statistically significant differences at level of $(0.05)$ among the students of the orientation year of FCIT of the years (2008, 2009, and 2010) with respect to GPA.

In order to verify this assumption, the researchers used analysis of variance of one direction. Table 4 shows the result of analysis of variance.

Table 4. Analysis of variance to determine variation of GPA among students of Orientation year.

\begin{tabular}{|c|c|c|c|c|c|}
\hline Source & Sum of Squares & Df & Mean Square & F & Sig. \\
\hline Between Groups & 148.428 & 235 & 0.632 & & \\
\hline Within Groups & 378.747 & 649 & 0.584 & 1.082 & .225 \\
\hline Total & 527.175 & 884 & & & \\
\hline
\end{tabular}


As presented in Table 4, there are no statistically significant differences among the students of the orientation year in FCIT of years $(2008,2009$, and 2010) with respect to GPA. Therefore, the students will be treated as one group irrespective of the year the student joined the orientation year.

\section{Hypothesis no. 2:}

The marks of students studying courses of the orientation year are normally distributed.

In order to verify this hypothesis, the research team calculated the coefficients of skewness of curves associated with those courses. Table 5 shows the results.

Table 5. The results of data analysis to calculate normality or skewness of distributions of student marks in courses of orientation year $(\mathrm{N}=\mathbf{8 8 5})$.

\begin{tabular}{|l|c|c|c|c|c|c|c|c|c|c|}
\hline & phys110 & math202 & math201 & math110 & math101 & math100 & elcs102 & elcs101 & cpit100 & cp201 \\
\hline Mean & 82.3085 & 82.9271 & 164.9638 & 83.3706 & 82.5345 & 83.4644 & 240.8260 & 81.4904 & 92.1503 & 78.6147 \\
\hline $\begin{array}{l}\text { Std. Error of } \\
\text { Mean }\end{array}$ & 0.40421 & 0.31720 & 0.68287 & 0.34171 & 0.33110 & 0.32067 & 1.42545 & 0.36807 & 0.16740 & 0.39734 \\
\hline $\begin{array}{l}\text { Std. } \\
\text { Deviation }\end{array}$ & 12.02490 & 9.43647 & 20.31474 & 10.16540 & 9.85002 & 9.53960 & 42.40562 & 10.94966 & 4.97994 & 11.82038 \\
\hline Variance & 144.598 & 89.047 & 412.689 & 103.335 & 97.023 & 91.004 & 1798.237 & 119.895 & 24.800 & 139.721 \\
\hline Skewness & -0.273 & 0.059 & -0.459 & 1.256 & -0.367 & -1.723 & -1.984 & -0.197 & -1.366 & 0.093 \\
\hline $\begin{array}{l}\text { Std. Error of } \\
\text { Skewness }\end{array}$ & 0.082 & 0.082 & 0.082 & 0.082 & 0.082 & 0.082 & 0.082 & 0.082 & 0.082 & 0.082 \\
\hline Sum & 72843.00 & 73390.50 & 145993.00 & 73783.00 & 73043.00 & 73866.00 & 213131.00 & 72119.00 & 81553.00 & 69574.00 \\
\hline
\end{tabular}

Table 5 indicates that the highest average or mean is obtained for (CPIT100) with the value of (92.15) and the lowest mean is obtained for (CPIT201). The coefficients of skewness are negative for some courses such as (CP201, ELCS101, ELCS102, MATH100, MATH101, and MATH201). This implies the high marks obtained by the students and the great correlation among them which can be used as an indication that the student marks are not normally distributed. However, the coefficients of skewness for (MATH202, and CPIT201) are close to the normal distribution since the value of correlation coefficient is approaching ZERO. On the other hand, the coefficient of skewness for (MATH110) is positive which means that student marks are close to each others. Fig. 10 shows those curves.

\section{Hypothesis no. 3:}

There is a positive statistical relationship at level (0.01) between the Grade Point Average (GPA) and student marks of courses of the orientation year in FCIT. 
In order to verify this hypothesis, the research team calculated the Pearson factor to determine the correlation between the GPA of the FCIT students of the batches 2008, 2009, and 2010 and their grades of some courses of the orientation year. The courses are: Computing, Mathematics, English and Physics. The results are shown in the matrix of Table 6.

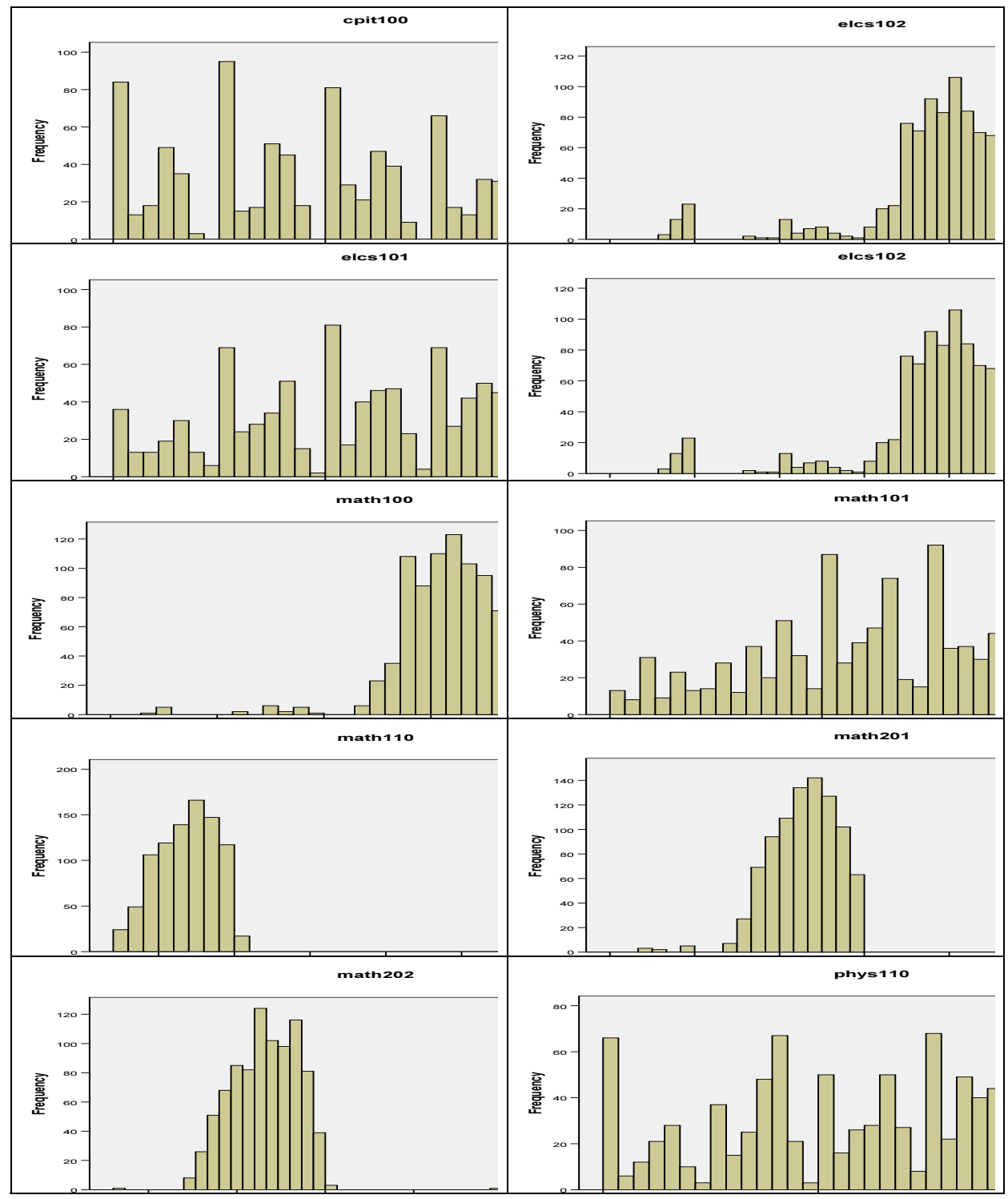

Fig. 10. Calculating the coefficients of skewness for some courses. 
Table 6. The matrix of coefficients of the relationship between the GPA and marks of some courses as well as the relationship among the courses.

\begin{tabular}{|c|c|c|c|c|c|c|c|c|c|c|c|}
\hline & $\begin{array}{c}\text { CPIT } \\
100 \\
\end{array}$ & $\begin{array}{c}\text { CP } \\
201 \\
\end{array}$ & $\begin{array}{c}\text { ELCS } \\
101 \\
\end{array}$ & $\begin{array}{c}\text { ELCS } \\
102 \\
\end{array}$ & $\begin{array}{c}\text { MATH } \\
100 \\
\end{array}$ & $\begin{array}{c}\text { MATH } \\
101 \\
\end{array}$ & $\begin{array}{c}\text { MATH } \\
110 \\
\end{array}$ & \begin{tabular}{|c|} 
MATH \\
201 \\
\end{tabular} & $\begin{array}{c}\text { MATH } \\
202 \\
\end{array}$ & $\begin{array}{c}\text { PHYS } \\
110 \\
\end{array}$ \\
\hline Mat & grad st & $.537(* *)$ & $.330(* *)$ & $.632(* *)$ & $.259(* *)$ & $.653(* *)$ & $.361(* *)$ & $.350(* *)$ & $.329(* *)$ & $.383(* *)$ & $.582(* *)$ \\
\hline CPIT100 & $5377^{* *}$ & 1 & $257(* *)$ & $468(* *)$ & $3711^{* * *}$ & $.792(* *)$ & $03(* *)$ & $\left.365^{* *}\right)$ & $32\left(2^{* *}\right)$ & $357(* *)$ & 414 (** $^{*}$ \\
\hline & $.330\left(^{* *}\right)$ & $.257(* *)$ & 1 & $.279(* *)$ & $.311(* *)$ & $.455(* *)$ & $.288(* *)$ & $198(* *)$ & $.226(* *)$ & $.261(* *)$ & $\left..2866^{* *}\right)$ \\
\hline ELCS1 & & $.468(* *)$ & $279^{(* *)}$ & 1 & $.361(* *)$ & $.715(* *)$ & & 310( & $.293(* *)$ & & $.528\left(^{* *}\right)$ \\
\hline & $\begin{array}{l}.259(* *) \\
\end{array}$ & $.371(* *)$ & $.311(* *)$ & $.361(* *)$ & 1 & $.485(* *)$ & $.099(* *)$ & $.116\left(^{* *}\right)$ & $.091{ }^{\prime}$ & .115 & $.224(* *)$ \\
\hline MAT & $653(* *)$ & $.792(* *)$ & $.455(* *)$ & $.715(* *)$ & $.485(* *)$ & 1 & $.342(* *)$ & $.369(* *)$ & $.329(* *)$ & .381 & $.513(* *)$ \\
\hline MAT & $51(* *)$ & $.303(* *)$ & $.288(* *)$ & $.330(* *)$ & $.099(* *)$ & $.342(* *)$ & 1 & $.721(* *)$ & $.823(* *)$ & $.917(* *)$ & $.297(* *)$ \\
\hline & $50(* *)$ & $.365(* *)$ & $.198(* *)$ & $.310(* *)$ & $.116(* *)$ & $.369(* *)$ & $.721(* *)$ & 1 & $.847(* *)$ & $.918(* *)$ & $195(* *)$ \\
\hline MATH201 & $.329(* *)$ & $.312(* *)$ & $.226(* *)$ & $.293(* *)$ & $.091(* *)$ & $.329(* *)$ & $.823(* *)$ & $.847(* *)$ & 1 & $.900(* *)$ & $.218(* *)$ \\
\hline MATH202 & $.383(* *)$ & $.357(* *)$ & $.261(* *)$ & $.344(* *)$ & $.115(* *)$ & $.381(* *)$ & $.917(* *)$ & $.918(* *)$ & .900 & & $.262(* *)$ \\
\hline PHYS110 & $.582(* *)$ & $.414(* *)$ & $.286(* *)$ & $.528(* *)$ & $.224\left(^{* *}\right)$ & $.513(* *)$ & $.297(* *)$ & $.195(* *)$ & $.218(* *)$ & $.262(* *)$ & 1 \\
\hline
\end{tabular}

( 0.01$)$ significant at $(* *)$

The results of Table 6 indicate the existence of a positive relationship between student marks of some courses in the orientation year and their GPAs. It shows also the existence of a statistical relationship at level (0.01). The maximum value is obtained with MATH100. The next value is associated with ELCE101 and the least value is associated with ELCE102 where the value obtained was (0.259).

\section{Hypothesis no. 4:}

The GPA of FCIT students can be expected through their marks of courses of the orientation year.

In order to verify this assumption, the research team used the method of Regular Gradient by using SPSS to determine the course that has the maximum contribution and effects (as independent variables) on the GPA as (dependent variable). The results are shown in Table 7.

Table 7 shows that the expectation of GPA of students of FCIT is based on the marks of six courses. They are: MATH100, PHYS110, ELCS101, MATH202, CPIT100, and ELCS102. The value of the Standard Error of Estimation is (0.551).

In fact, the six courses contribute by up to $(\mathrm{R} 2=55.4 \%)$ in the expectation of GPA of the students. Moreover, the course MATH110 is the most course that contributes most for the expectation process since it contributes up to $(42.7 \%)$. Next to that is PHYS110 where its contribution is $(8.35 \%)$. Then ELCS101 follows with the contribution of $(0.27 \%)$. The other courses, i.e. MATH202, CPIT100 and ELCS102 contribute with $0.11 \%, 0.03 \%$, and $0.03 \%$ respectively. The other courses 
of the orientation year have their contribution for the expectation of the GPA, however, they do not have a significant statistical contribution. There are factors that can be used as tools to determine the expectation of the GPA for the students.

Table 7. The constant value for Regular Gradient analysis according to the sequence of independent variables and their statistical implication for expecting the dependent variable.

\begin{tabular}{|c|c|c|c|c|}
\hline Model & Constant & $\mathrm{R}$ & $\mathrm{R}^{2}$ & $\begin{array}{r}\text { standard Error } \\
\text { of Estimation }\end{array}$ \\
\hline $\begin{array}{l}\text { First } \\
\qquad \begin{array}{l}\text { Constant } \\
\text { MATH } 100\end{array}\end{array}$ & $\begin{array}{c}-0.100 \\
0.048\end{array}$ & $0.653(a)$ & 0.427 & 0.426 \\
\hline $\begin{array}{l}\text { Second } \\
\text { Constant } \\
\text { MATH100 } \\
\text { PHYS110 }\end{array}$ & $\begin{array}{l}-0.659 \\
0.036 \\
0.017 \\
\end{array}$ & $0.714(b)$ & 0.510 & 0.509 \\
\hline $\begin{array}{l}\text { Third } \\
\text { Constant } \\
\text { MATH100 } \\
\text { PHYS110 } \\
\text { ELCS101 } \\
\end{array}$ & $\begin{array}{c}-0.698 \\
0.025 \\
0.017 \\
0.015 \\
\end{array}$ & $0.733(\mathrm{c})$ & 0.537 & 0.535 \\
\hline $\begin{array}{l}\text { Forth } \\
\text { Constant } \\
\text { MATH100 } \\
\text { PHYS110 } \\
\text { ELCS101 } \\
\text { MATH202 }\end{array}$ & $\begin{array}{c}-1.124 \\
0.023 \\
0.016 \\
0.014 \\
0.009 \\
\end{array}$ & $0.740(d)$ & 0.548 & 0.546 \\
\hline $\begin{array}{l}\text { Fives } \\
\text { Constant } \\
\text { MATH100 } \\
\text { PHYS110 } \\
\text { ELCS101 } \\
\text { MATH202 } \\
\text { CPit100 } \\
\end{array}$ & $\begin{array}{r}-1.014 \\
0.016 \\
0.016 \\
0.015 \\
0.008 \\
0.005 \\
\end{array}$ & $0.743(\mathrm{e})$ & 0.551 & 0.549 \\
\hline $\begin{array}{l}\text { Six } \\
\text { Constant } \\
\text { MATH100 } \\
\text { PHYS110 } \\
\text { ELCS101 } \\
\text { MATH202 } \\
\text { CPit100 } \\
\text { ELCS102 } \\
\end{array}$ & $\begin{array}{c}-0.931 \\
0.018 \\
0.016 \\
0.016 \\
0.008 \\
0.005 \\
-0.001 \\
\end{array}$ & 0.744 (f) & 0.554 & 0.551 \\
\hline
\end{tabular}

$1-\mathrm{Y}_{1}=-0.100+0.048 \mathrm{MATH} 100$

2- $\mathrm{Y}_{2}=-0.659+0.036 \mathrm{MATH} 100+.017$ PHYS 110 
3- $\mathrm{Y}_{3}=-0.698+0.025$ MATH100+.017 PHYS110+.015 ELCS101

4- $\mathrm{Y}_{4}=-1.124+.023 \mathrm{MATH100+0.016} \mathrm{PHYS110+0.014} \mathrm{ELCS101+}$ 0.009 MATH202

5- $\mathrm{Y}_{5}=.-1.014+.016 \mathrm{MATH} 100+.016 \mathrm{PHYS} 110+.015 \mathrm{ELCS} 101+.008$ MATH202+.005 CPit100

$6-\mathrm{Y}_{6}=-.931+.018$ ATH100+.016 PHYS110+.016 ELCS101+.008 MATH202+.005 CPit100 -.001 ELCS102

The above equations could be used to expect the GPA of students of FCIT from their grades of the orientation year.

\section{Conclusion}

As shown from the literature review, many resources can give many KPIs. Also, different software is available to decide KPIs. However, each institution or organization has to decide on their own KPIs that measure their performance since they are the ones who know their objectives the best.

On the other hand, it turns that the MATH course is the primary indicator for the expected GPA. The better grade is the better GPA as well as good performance through studying years in FCIT.

\section{Acknowledgement}

This project was funded by the Deanship of Scientific Research (DSR), King Abdulaziz University, Jeddah, under grant no. (256/611/431). The authors acknowledge DSR for financial support.

\section{References}

[1] http://www.studentprogress.org/

[2] http://management.about.com/cs/generalmanagement/a/keyperfindic.htm

[3] http://ideas.repec.org/p/pra/mprapa/13621.html

[4] http://www.education.ky.gov/kde/instructional+resources/curriculum+documents + and + resources/student+performance+standards/

[5] http://ec.europa.eu/education/pdf/doc282_en.pdf

[6] Balakrishnan Muniandy, Mei Yean Ong, Kia Kien Phua, and Saw Lan Ong, "Assessing Key Performance Indicators Monitoring System (KPI-MS) of a university using Technology Acceptance Model", International Journal of Social Science and Humanity, 1(3): September (2011).

[7] Balakrishnan Muniandy, Mei Yean Ong, Kia Kien Phua and Saw Lan Ong, "User Acceptance of a Key Performance Indicators Monitoring System (KPI-MS) in Higher 
Education: An Application of the Technology Acceptance Model", 2nd International Conference on Education and Management Technology, IPCSIT, 13: IACSIT Press, Singapore, (2011).

[8] Lee Sing Kong, "Major Factors of Success and Failures in Preparing and Implementing Strategic Plan for an Academic Organization", Nanyang Technological University, presentation from www.ntu.edu.sg.

[9] "Key Performance Indicators: A Guide for Assessment and Quality Enhancement for Universities in the Islamic World", Extraordinary Session of Islamic Conference of Ministers of Higher Education and Scientific Research, Riyadh, Kingdom of Saudi Arabia, 4-5 October, (2011).

[10] Maria da Conceição da Costa Marques, "Key performance indicators in Portuguese public universities",

[11] Strategic Plan (2010-2015), The University of Shiffield. 
إيجاد مؤشرات رئيسية جديدة لقياس الأداء لكلية الحاسبات وتقنية المعلومات بجامعة الملك عبدالعزيز

كمال جمبي، وحسانين البرهتوشي، ووجدي الجوديبي، وراضي طلب

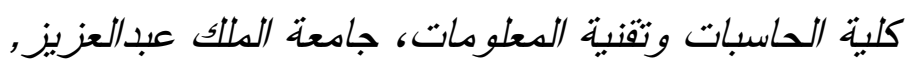
جـة - المملكة العربية السعودية

المستخلص. يعرض هذا البحث مؤشــرات الأداء الرئيسـة لكليــة

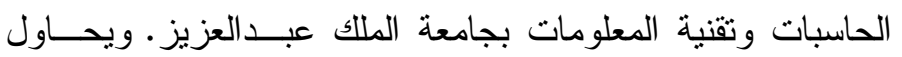
البحث الإجابة على التساؤلات النالية:

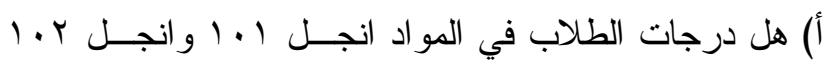

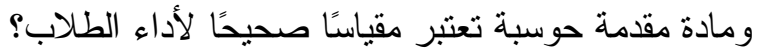

ب) هل يمكن استخدام مادة الرياضيات ر • 11 للأداء للقياس؟ ج) هل المعدل التراكمي للمواد العامة في الكلية وهي (مقدمة

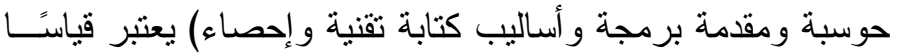

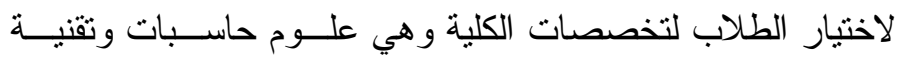

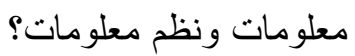

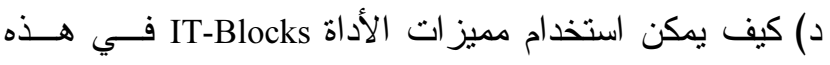

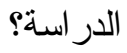

هـ) لماذا تتفوق الطالبات على الطلاب في الكلية؟

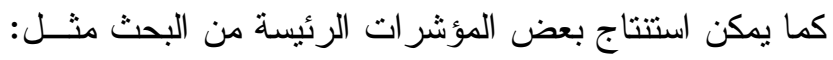

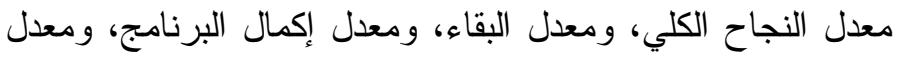
المواد/السنة السجلة، وخريجي الكلية. 